\title{
Itkud ja itkejad biograafilisest vaatepunktist: välitöödel talletatud materjali analüüs ${ }^{1}$
}

\author{
Natalia Ermakov \\ Eesti Keele Instituudi eesti-ersa sõnaraamatu koostaja \\ ermakov.natalia@gmail.com
}

\begin{abstract}
Teesid: Artiklis vaadeldakse itkutekste ja itkejate elulugusid ning itkemisega seotud tavandilist konteksti. Uurimismaterjalist on toodud teksti-, heli- ja videonäiteid. Analüüsitavad elulood ja itkud on kogutud ajavahemikus 2000-2013 (Ermakov 2011; 2014: 16-24) ja need pärinevad Mordva vabariigi Ardatovo rajooni pärimusainesest (vaata kaarti). Mordvalased on Venemaal elav soomeugri rahvas, kellel on Vene Föderatsiooni koosseisus oma vabariik (26 200 km² $^{2}$, pealinn Saransk). 2010. aasta rahvaloenduse andmetel elas Venemaal 834755 mordvalast (http://www.emordovia.ru/content/view/874.15.01.2013). Enamasti tuuakse uurimustes esile, et mordvalastele on omane binaarsus, kuna mordva seob endas kahte etnilist rühma: mokšasid ja ersasid. Mõlemal on oma eneseteadvus, keel ja kultuurilised iseärasused (Kornišina 2005: 6). Küsitletavad on sündinud 1920. aastate lõpul, 1930. aastate alguses. Võrdluseks on küsitletud ka noorema põlvkonna esindajaid, kelle sünniaastad jäävad vahemikku 1964-1980. Nad kõik on pärit maalt. Itkejate elulugude ja itkutekstide kaudu võib saada aimu omaaegsest kultuurilisest ja ajaloolist keskkonnast. Olles ise käsitletava traditsiooni keskel kasvanud, olid autoril head eeldused materjali kogumiseks ja interpreteerimiseks. Artiklis esitatakse ka tähelepanekuid itkude jäädvustamise usundiliste tabude kohta. Ühtlasi kirjeldatakse itkejaid nende vahetus elukeskkonnas.
\end{abstract}

Märksõnad: elulugu, ersa-mordva itk, folkloristlikud välitööd, maaelu

Artikli eesmärk on vaadelda itkemise, itkude ja itkejate elukeskkonda, keskendudes itkudes sisalduvatele eluloolistele aspektidele. Kuna itk on traditsiooniline kurbuse ja leina väljendamise vorm, siis on see poeetiliselt üsna väljakujunenud esituskeelega žanr. Samas on itk ja itkemine seotud inimese elukäigu etappidega ja on alati personaalne, mis annab põhjuse vaadelda itkutraditsiooni biograafilisest vaatepunktist. Artikli esimeses osas tutvustatakse välitöödel talletatud analüüsimaterjali ja antakse ülevaade mordva, eriti ersa itkutraditsioonist. Artikli teises pooles tutvustatakse itkejaid nende omaelu- 
looliste ja välitöödel kogetud lugude kaudu ning analüüsitakse itkutekstide kujundkeelt, osutades sajandite jooksul välja kujunenud poeetika (kollektiivi ühiskeele) seotusele konkreetse ajaloolise ja personaalse juhtumiga. Artikli lõpus on pühendatud tähelepanu itkude tänapäevastele esitustele.

\section{Artikli teoreetilised ja metoodilised lähtekohad}

Elulugude ja itkude omavaheliste seoste uurimiseks kogusin ainest välitöödel. Materjali analüüsimisel lähtusin nii materjali interpretatsioonist kui ka kontekstianalüüsist. Kasutasin nii žanrilist, semantilist kui ka temaatilist analüüsi.

Kui uurimuse seisukohast on oluline teada, kuidas folkloori erinevates situatsioonides kasutatakse ja esitatakse, siis on materjali kogumisel vaja rakendada erinevaid kogumisstrateegiaid (Jackson 1987: 104; Korb 2007: 42). Naistega välitöödel vesteldes kasutasin empiirilise materjali kogumiseks esmalt suulist intervjueerimist ja küsitlemist vaba vestluse vormis etteantud teemal. Intervjuu toob esile ainult osa informatsioonist, sest küsitletav ei pruugi alati tahta vastata kõikidele küsimustele. Samuti erineb küsitlemissituatsioon sellest, kui pärimust viljeldakse selle loomulikus esituskeskkonnas. Näiteks on Lauri Honko oma artiklis "Folklooriprotsess" öelnud, et teatud juhtudel peab uurija leidma kontakti uuritava ühiskonna liikmetega, kes antud ainestiku loovad, kasutavad ja alal hoiavad (Honko 1998: 59). Teiseks kasutasin osalusvaatlust, mille raames käisin aastail 2000-2013 kolmeteistkümnel korral kalmistupäevadel; 2010. aastal osalesin ühel peretuttava, vanemaealise mehe matusel; kolmel korral jälgisin pulmi (1999. aastal abiellus tädipoeg, 2000 onutütar ja 2002 õde), samuti osalesin sugulaste sõjaväkke saatmisel. Osalusvaatluste käigus tehtud tähelepanekuid ja üleskirjutusi kasutan artiklis empiirilise allikana. Välitööde käigus kirjutasin vanematelt inimestelt üles traditsioonilisi kombeid ja itke (pulma- ja surmaitkud, noormeeste sõjaväkke saatmise tavad, sellega seostuvad itkutekstid jne), noorematelt tänapäevaseid kombeid (nt pulmad ja sõjaväkke saatmised praegu).

Kogutud materjal on ülekaalukalt saadud eakatelt informantidelt, kellest artikli kirjutamise ajaks on juba üle poole lahkunud teispoolsusesse. Küsitletavaid oli 50, neist 45 oli ersa ja viis mokša rahvusest. Enamik informantidest olid vanuses 65-84, keskmine vanus 70 aastat, kuid oli ka nooremaid, 30-45 aastaseid, kes tundsid mõningal määral itkutraditsiooni ja valdasid pärimust. Osalt olid nad vanemate küsitletute lapselapsed või sugulased. Küsitletuist valdav osa olid naised, kuid nende seas oli ka kolm meest (vastavalt 43-, 81-, 78aastane). Kõik nad tundsid itkudega seotud kombeid ja uskumusi väga hästi. 
See on haruldane, et mehed tahavad rääkida itkudest ja kombestikust, sest ka Mordvas (nagu näiteks ka Setumaal ja Kihnus) on kombestiku ja siirderiitustega seotud pärimuse alahoidjad valdavalt naised. Paljud küsitletuist olid oma külas ka rahvakultuuri propageerijad ja populariseerijad: nad tegutsesid kultuuritöötajate, tuntud rahvalaulikute, nutunaiste, ravitsejate ja õpetajatena. Nende osa kogukonna pärimuse kujundamisel on märkimisväärne: nad korraldavad traditsioonilisi üritusi nagu pulmad, matused, surnute mälestamine, sõjaväkke saatmised. Neid ülesandeid täites loovad ja kujundavad nad oma tegevuse kaudu pärimustraditsiooni. Lauri Honko juhib tähelepanu sellele, et just eelkirjeldatud rolli kandvad tegelased suudavad pärimusainesest uusi teadmisi esile tuua (Honko 1998: 78-79). Osa küsitletuist elab Eestis, ent nad on kodumaalt kaasa võtnud väärt teadmisi ja oskusi oma pärimuskultuurist. Antud artikli tarvis valisin kirjeldatud välitöömaterjalist vaid mõne itkeja eluloo ja itkud. Valik lähtus sellest, kellega kujunes välitööde käigus tihedam koostöö.

\section{Itkud}

Uurijad on täheldanud, et itkuluule on olemas väga paljudel rahvastel kogu maailmas. Teiste seas tunnevad itke ka soome-ugri rahvad, sealhulgas läänemeresoomlased (Sarv 2000: 97). Mordvalaste surmaitke ja nutulaule hakati uurima varem kui mordvalasi ja mordva keelt üldse. Mordvalastel, nagu paljudel teistel rahvastel, on olemas surma-, mõrsja- ja nekrutiitkud. Teatud määral on mordva itkud kasutuses ka tänapäeval.

Itk (ersa k. лайшела, урнела, авардела) on traditsioonilises mordva kultuuris kellelegi adresseeritud monoloog ning väljendab muret, kurbust ja leina. See on naiste traditsiooniline laulev-retsitatiivne improvisatsioon, mida esitatakse selliste rituaalide läbiviimisel nagu matused, pulmad, noormeeste saatmine sõjaväeteenistusse, samuti nii ühiskonna- kui ka pereelus toimunud õnnetuste või kurbade sündmuste puhul. Mordva traditsioonis kasutatakse matuse-, nekruti- ja olustikuliste itkude puhul terminit лайшелат, samas pulmaitkudel on olemas oma termin: урнелат või аварькшнелат.

Itkus domineerib poeetiline monoloog, mis on osa surnute ja elavate, inimeste ja jumalate vahelisest suhtlusest. Itk sünnib improvisatsioonina, kus lähtutakse teemadest, mille motiivid on paljudel juhtudel arhailised. Mitmed uurijad on osutanud sellele, et itkeja ei toimi ainult elavate ja surnute vahendajana, vaid ta on ühtlasi ka lahkunu saatja (vt lähemalt Arukask 2011: 44).

Itkul on traditsiooniline ülesehitus, mille abil luuakse kodust või maailmast lahkunule adresseeritud poeetiline pöördumine. Selles kasutatakse enamasti 
ainsuse teist pööret (sina-vormi) ja mitmuse esimest pööret (meie-vormi) ning tegusõnu käskivas kõneviisis. Rohkesti leidub itkudes traditsioonilisi poeetilisi võtteid nagu metafoore ja hüperboole (Ятноень коронь кирделе-vaenlaste tuju järgi elaта, Чужоень мельтне мелекшевт - võõrastel on meeleolu muиtlik, Ятноень кортнэ корокшовт - vaenlaste tavad on erinevad; Сиянь жарокс кеверезь - keereldes nagu hõbedane pall, Шёлконь лентакс каладозь - lahti seotud nagu siidine lint); võrdlusi (Мазый цеця лацо сезилек- muljusid mind nagu lillekest, Пиже тикше ладсо костилек - kuivatasid mind nagu heina), epiteete (Пижинеть мазый дугинеть - ilusad rohelised sõbrannad, Пиже mяка - roheline laps, Пиже нарлунь - roheline lind). Osa ersa-mordva itkude vormitunnustest, nagu alliteratsioon ja sünonüümne parallelism, on omased ka läänemeresoome itkudele ja regilauludele. Monoloog näib olevat itkude üldisem tunnus. Itk on unikaalne: traditsioonilisi elemente kasutades loob itkeja iga kord ainulaadse teose.

Võib eristada tavandi- ja olustikuitke. Siinjuures kattub uurijate määratlus ja terminoloogia itkejate endi määratlusega. Tavandiitkud on seotud inimelu pöördeliste sündmustega, siirdumisega ühest olukorrast teise. Itkudega saadetakse surnuid kujuteldavasse teispoolsesse maailma (surnuitkud), mõrsjaid vanemate kodunt mehekoju (pulmaitkud), mehi, peige, poegi ja vendi rahulikust kodusest elust sõjateele (nekrutiitkud). Olustikuitkud seostuvad aga erinevate ootamatute õnnetustega peres või kogukonnas.

Itkud kuuluvad rituaalse rahvaluule žanrite hulka mida võib tänapäeval küllaldaselt leida mitte üksnes ersa, vaid ka teiste soome-ugri rahvaste juures. Et nutulaulu tõlgendada, on vaja itkuteksti analüüsida kombestiku ja selle kasutamisega seotud olukordade kontekstis (vrd Pino 2000: 42).

\section{Ersa itkutraditsiooni ajalooline taust}

Mordvalaste peamine religioon 18. ja 19. sajandil oli rahvapärane õigeusk, milles põimusid eelkirstlikud ja õigeusukombed. Itkemise traditsiooni taandumisele mõjus kindlasti kaasa ka kiriku vaenulik hoiak. On teada, et eriti protestantlik kirik taunis rahvasundi ja kommete järgimist, sealhulgas ka pulma- ja matusekombeid. Ka Venemaa õigeusukirik taotles rahvapärase itkemiskombe väljajuurimist. Nii ametlik kirik kui ka riik võitlesid itkude vastu sajandeid, manitsedes rahvast järgima kiriku ja riigi seadusi, samas Mordvamaa talupoegade ja itkutraditsioonini need keelud enamasti ei ulatunud. Mordvamaal lihtsalt ei tekkinud sellist institutsiooni, mis oleks suutnud täita samalaadset funktsiooni nii, et inimesed oleksid sellega rahule jäänud. Lauri Honko kirjutab itkemise funktsioonist järgmiselt: itkemise kõige üldisem eesmärk oli elu 
jätkamise kindlustamine hõimurühmas. Oli vaja täita lahkunu soovid, et olla kindel teispoolsusesse siirdunu heatahtlikkuses sugulaste suhtes ning elimineerida võimalik pahatahtlikkus (Honko 1963: 81-121).

Mida on teada mordva usundilisest traditsioonist? Esimesed teated mordva rahvauskumustest ja rituaalidest esinevad 13.-17. sajandist pärit reisikirjades ja kroonikates, mille autoriteks on omaaegsed maadeavastajad ja saadikud: flaam Vilhem Rubruk, itaallane Giosafat Barbaro, inglane Giles Fletcher, rootslane Petrus Petrejus ${ }^{2}$, hollandlane Nicolaes Witzen jt. Nende autorite kirjeldustes on mordvalased paganausulised (Kornišina 2000: 5-6). 18. ja 19. sajandi alguse uurimused pakuvad pelgalt fragmentaarse ettekujutuse mordvalaste rituaalidest, usundist, kommetest ja rahvaluulest. Esiteks on see seotud asjaoluga, et uurijatel polnud võimalik kohalike rahvaste kultuuri detailsemalt tundma õppida ajapuuduse ja keeleoskamatuse tõttu. Nende eesmärgiks oli toonase Venemaa rahvaste kaardistamine ja üldine kirjeldamine. Peale selle oletasid neist paljud, et mordva rahvaste (ersade ja mokšade) kristianiseerimine, mida vene võimud sel ajal intensiivselt läbi viisid, tõi kaasa rohkete õigeusuelementide imbumise mordva kultuuri ja rituaalsesse sfääri sealhulgas (Devjatkina 1992: 7). Ka on märkimisväärne, et tollal ei teinud paljud uurijad ersadel ja mokšadel vahet, vaid nimetasid mõlemaid mordvalasteks.

Mordvalaste massiline ja sunniviisiline ristimine toimus 18. sajandi esimesel poolel. Samal ajal levis ka vene keele oskus ja sagenesid segaabielud. Ristimine oli riigi asi, poliitiline aktsioon, mida ei surunud rahvale peale kirik. Riigi keskvõim läkitas saadikud Venemaa eri paigus elavate rahvaste juurde, et levitada nende hulgas õigeusku ja propageerida uut ühiskondlik-poliitilist elukorraldust. Tänapäeval on valitsevaks religiooniks saanud õigeusk, mis on ka itkutraditsiooni taandumise üks põhjus.

19. sajandil olid mordvalased valdavalt kirjaoskamatu talurahvas. 19. sajandi lõpul ja 20. sajandi alguses andsid mordva kultuuri kirjeldamisse ja uurimisse oma panuse Aleksandr Šahmatov, Makar Jevsevjev ja Mihhail Markelov. Tuntud vene teadlane Aleksandr Šahmatov koostas Peterburis 1910. aastal "Mordva etnograafia kogumiku", kus ta esitas ka mõned pulma-ja matuseitkud. 19. sajandi lõpul hakati arendama mordva kirjakeeli ning tekkis väikesearvuline mordva haritlaskond, kes huvitus rahvakommetest ja folkloorist. Mordva esimese põlvkonna väljapaistvaim haritlane oli Makar Jevsevjev (1864-1931). Tema märkimisväärseks uurimuseks (sh ka itkukultuuri vallast) on "Mordva pulm". Selle uurimuse tarvis alustas ta materjali kogumist 1880. aastal ja esimest korda publitseeris ta mõned toona kirja pandud itkudest 1892.-1893. aastal. Tervikuna ilmus see uurimus 1931. aastal (Jevsevjev 1961-1966; 2004).

20. sajandi teisel poolel algas mordva rahvaluule, selle erinevate žanrite ja arengusuundade süsteemne uurimine. Sellele pani aluse Nõukogude Liidu 
Teaduste Akadeemia Etnograafia Instituut, kes koos Mordva õpetlastega korraldas ekspeditsioone empiirilise materjali kogumiseks piirkondades, kus elasid mokšad ja ersad (Mordva, Tatari, Baškiiri ja Tšuvaši vabariik ning Pensa, Nižnegorodi, Samaara ja Orenburgi oblast).

1950. aastatest alates osalevad mordva rahvakultuuri uurimisprotsessis aktiivselt ka uue põlvkonna kohalikud uurijad: etnoloogid Nadežda Beljaeva, Galina Kornišina, Nikolai Mokšin, folkloristid Andrei Borissov, Marija Jefimova, Mihhail Imjerekov, Valentina Imaikina, Anatoli Samoškin, Aleksandr Šaronov, Aleksei Šuljaev, Mihhail Tšuvašev, Tatjana Devjatkina. Kõige põhjalikumalt neist on itkutraditsiooni uurinud Tatjana Devjatkina, kes avaldas oma töö tulemused mokša pulma teemalises monograafias. Ta näitab mokša erinevate kogukondade pärimuse erijooni, nende algupära ja itkude seotust rahvakommetega. Samas toob ta välja paralleele mokša ja ersa pulmaitkude ja -tavade vahel. Oma uurimuses juhib Devjatkina tähelepanu sellele, et mokša pulmaitke on kogutud tunduvalt vähem kui ersa omi (Devjatkina 1992). Ersade ja mokšade itkud on väga sarnased ülesehituse, funktsiooni ja poeetilise keele poolest, neid rahvaid eristab ainult lokaalne erinevus - ersade paiknemine on hajutatud üle kogu Venemaa.

Pilk varasematele uurimustele näitab, et mordva (sealhulgas ersa) itkutemaatikat on senini erinevatel põhjustel (nt suletud pärimus) ebapiisavalt käsitletud. Hoopis tähelepanuta on jäänud selline uurimisvaldkond nagu itkejate elulood.

\section{Itkutekstide salvestamine ja koostöö informantidega}

Informantidega kontakti leidmine ja koostöö mulle üldjuhul raskusi ei valmistanud, kuigi mõningaid probleeme esines. Orienteerun küll hästi uuritavas sotsiaal-kultuurilises keskkonnas, kuid mõnikord oli ka minul üsna keeruline seda ainestikku koguda. Suurem osa inimesi, kellelt empiirilist materjali kogusin, sai aru, miks ma seda teen ja milleks see on vajalik (kogun materjali ja salvestan seda tulevaste põlvede ja tulevaste uurijate tarbeks). Samas tegin seda pärimuse kandjana ja kogukonda kuuluvana ehk nn ühe jalaga seesolijana. Ma tundsin, et minu huvi intiimsete teemade vastu, olgugi uurimiseesmärgil, on probleemne. Näiteks surmaitkud ja sellega seonduv on aines, mis tavapäraselt ei ole avalikkusele suunatud: see ei ole n-ö etnoloogiline performance, see materjal ei kuulu ka folkloorifestivalide kavadesse. Eelnevast tulenevalt ei saa seda salvestada ega taasesitada tehniliste vahendite abil (kuigi nüüdisajal on seda hakatud tegema). 
Olulised raskused tekkisidki siis, kui salvestasin matuse- ja peieitkusid video- või audioseadmetele seal, kus informant ei soovinud avalikustada oma elu kurbi hetki - seda kõrvaltvaatajale avada või talletada. Samuti ei taheta tavaliselt esitada itkusid väljaspool kombetalitust, s.t eraldi salvestuse tarbeks. Esitajad kardavad, et kuna itkemine ilma põhjuseta on tabu, võib see kaasa tuua kurbi tagajärgi. Peale selle on oluline ka isiklik moment: itku sooritav nutunaine elab tugevasti rolli sisse, hakkab nutma ega suuda hääldada sõnu (see käib ka noorte kohta).

Välitööl juhtus minuga huvitav lugu. Üks minu koduküla hea tuttav teadjaravitseja keeldus mitu aastat mulle intervjuud andmast. Ja äkki ühel suvalisel päeval nagu teisipäev või neljapäev võisin minna kaameraga tema juurde. Enne minu tulekut ta palus, et tooksin talle metsast allikavett. Me vestlesime õues pikalt ja siirdusime siis tuppa. Enne majja astumist sõnas ta: "Minu majja midagi sisse ei tule ja ei lähe ka välja.” Ma ei pööranud tema ütlemisele suurt tähelepanu ja küsitlesin rahulikult edasi. Koju jõudnud, avastasin, et minu salvestatud materjal on mingil moel kadunud. Järgmisel päeval läksin tema juurde ja rääkisin juhtunust. Ta vaatas mulle muiates otsa ja ütles: "Kõik, mida minu majas tehakse, ei ole võorraste silmade jaoks." Siis ma sain aru, et ta andis mulle õppetunni ja hoiatas, et selle teemaga tuleb olla väga ettevaatlik. Ma tänasin teda ja järgisin edaspidi seda nõuannet. Taolisse olukorda on sattunud ka teised folkloristid. Näiteks Makar Jevsevjev tõdes: "See oli mitte ainult raske, vaid tihti ka ohtlik. Eriti siis, kui tegemist oli religioossete rituaalide filmimisega, sakraalsete atribuutide puutumisega nagu näiteks küünal, mida kasutati palvustel. See küünal süüdati ainult kord aastas ja muul ajal seda puutuda ei tohtinud. Usuti, et küünla rahu häirimine võib põhjustada halba mitte ainult sellele inimesele, kes küünalt puudutas, vaid kogu külale" (Jevsevjev 2004: 8). Kohalike õpetajate abil õnnestus tal 1912. aastal osaleda Penza oblasti Volgapino külas (mokša küla, tänapäeval on see Kovõlkinski rajoonis) kahel palvusel. "Küla palvusele pääsemine oli väga keeruline" (Jevsevjev 1961-1966: 5, 351). Kord saabunud ta Keretino külla, kus lapsed kaigastega väravatele lüües ringi jooksid, kutsudes rahvast palvusele. Jevsevjev pani fotoaparaadi sündmuse jäädvustamiseks valmis, kuid poole tunni pärast tuli külavanem koos külarahvaga ja palus tal palvuselt lahkuda. "Ei aidanud külaõpetajate soovitused ega minu seletused, ma pidin lahkuma" (Jevsevjev 2004: 9).

Mis puutub pulmaitkudesse, siis siin oli olukord vastupidine: informandid esitasid neid hea meelega. Pulmad või osa pulmarituaale on selline folkloorne materjal, mida, vastupidiselt matustele, esitatakse meelsasti folkloorikavadena. Ühtlasi on see rahvaluuležanr üks armastatumaid ning seda oli kerge üles kirjutada, mistõttu õnnestus mul seda materjali koguda suurel hulgal, kuid siiski üksnes eakatelt inimestelt. 


\section{Itkud ja itkejad: elulooline taust}

Elulood ja itkud on omavahel läbi põimunud. Järgnevas alapeatükis on neid põimumisi vaadeldud mitmelt tasandilt: itku tegelaste lood, itkejate lood ning itkeja ja uurija omavaheliste seoste tasand. Itkejate elulood on esitatud nii, nagu nad ise sellest kõnelesid - see on nende kui itkejate enesevaade. Itkude tekstinäited on toodud kohalikus, Ardatovo rajooni dialektis.

Võimeka itkeja prestiiž külakogukonnas on olnud kõrge nii varasematel aegadel kui ka tänapäeval. Üheks märkimisväärseks informandiks, kellega uurijana kohtusin, oli Aleksandra Kuznetsova (1927-2010) Ardatovo rajooni Tšukalõ külast. Järgnev eluloojutustus pärineb Aleksandra enda esitusest. Aleksandra töötas pensionile jäämiseni külanõukogu sekretärina. Ta oli pärit oma kogukonnas lugupeetud perest. Tema isa oli kohaliku kolhoosi kolmas esimees. Sellest hoolimata teadmata põhjusel ta vangistati. Kui Aleksandra ema läks meest vanglasse vaatama, et uurida, miks abikaasa Nikolai vangi pandi, siis vangistati ka tema. Pärast neid vahejuhtumeid jäi Aleksandra orvuks. Lapsepõlv ilma isa ja emata õpetas Aleksandrat olema tugev ja järeleandmatu. Samas oli ta lapsest saadik väärtustanud oma rahva ja küla pärimust. Alates 1982. aastast tegeles Aleksandra küla folklooriansambliga Ersa Naised. Ta kirjutas ise laule, nii lühikesi ja lõbusaid kui ka kurva sisuga laule, milles ta kirjeldas eluraskusi, võttes teemasid oma lapsepõlvest ja perest. Aleksandra osales mitmetel festivalidel, sealhulgas ka Eestis 2009. aastal toimunud ersa keele päevadel. Küpsemas eas hakkas ta itkejanaiseks ning vaimulike laulude esitajaks matustel ja peiedel, saavutades selles valdkonnas tuntuse.

Aleksandraga sidus mind isiklikult ka üks rahvariietega seotud lugu. Nimelt olin ma aastatel 2007-2013 tihti tema kodukülas välitöödel. Mul õnnestus temaga mitmeid kordi erinevatel teemadel vestelda. 2008. aasta suvel rääkisin talle oma soovist osta endale "päris" rahvariided. Ta saatis mind ühe naise juurde, kuid see naine keeldus mulle oma rahvariideid müümast, selgitades, et tegemist on tema suririietega. Samas hakkas Aleksandrat huvitama minu päritolu: ta küsis näiteks, kellena töötavad minu ema ja isa, vanaisa ja vanaema. Järgmisel, 2009. aasta suvel otsustas ta oma perekonnaga, et pärandab oma rahvariided mulle, põhjendades oma otsust sellega, et tegelen ersa kultuuriga ja olen seega ersa rahva väärikas esindaja. Samal aastal sain ka teada, et Aleksandra oli ühendust võtnud ühe oma koduküla inimesega, kes oli abiellunud minu külla, et põhjalikumalt küsida minu perekondliku tausta kohta. Aasta hiljem - 2010 - ta suri. Suhtlen siiani tema sugulastega. Ühtlasi olen käinud ka kalmistul teda külastamas ja tänamas.

Aleksandra itkulauludest valisin lähemaks vaatluseks pulmalaulu, kuna see tekst on analüüsimiseks äärmiselt huvitav. Pruudi pulmaitkud on imelisemaid 


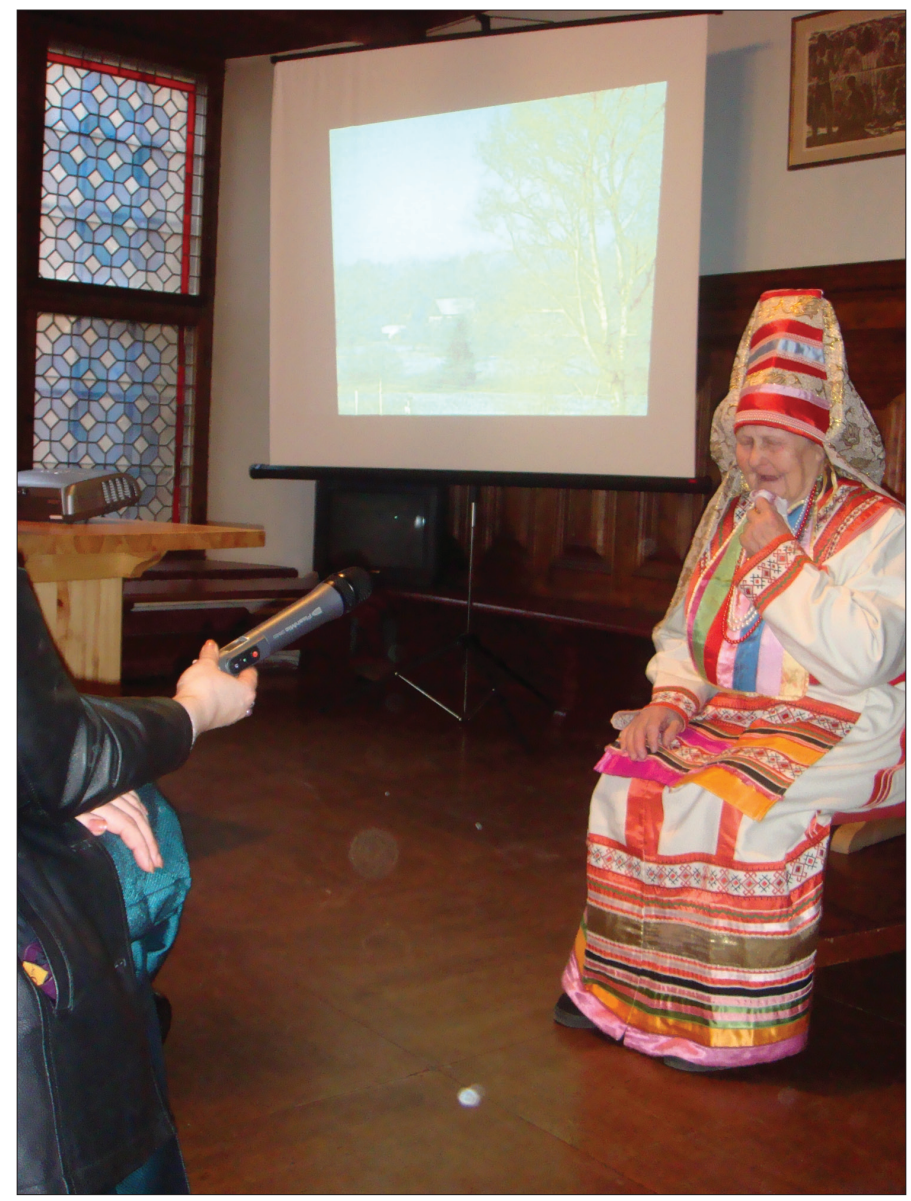

Aleksandra Kuznetsova (1927-2010), Tšukalõ küla.

Natalia Ermakovi foto 2009.

ja ilusamaid rahvaloominguteoseid, mis minevikus olid mordva pulmakombestiku kohustuslikuks komponendiks. Neis itkudes on hingeliigutused, unistused, ootused, lootused. Neid kuulasid lapsed, kellele pulm oli üks huvitavamaid vaatemänge. Jumalagajätus isamajaga, hiljem kodukandiga, asulaga, külaga väljendus armastus kodu, vanemate, lähedaste sugulaste ja sõbrannade vastu. Muistsete traditsioonide hoidmisel olid hilisemates pulmaitkudes tähtsal kohal sotsiaalsed teemad. Tänapäeva ersa pulmades rahva traditsioonilisi pulmakombeid üldiselt ei järgita ega esitata ka pulmaitke. Jälgida võib vaid mõnda arhailist kommet, mis on seotud esivanemate kultusega (näiteks haudadel itkemine). See komme oli ka setudel (Rüütel 2009: 69). 
Kui varasemas traditsioonis käis neiu enne pulmi kalmistul itkemas ja esivanematelt õnnistust palumas, siis tänapäeval on see komme transformeerunud ja kalmistu asemel käiakse langenud sõduri mälestussamba juures.

Siin vaadeldav Aleksandra itk oli kasutusel 1950. aastate pulmades, kus itkul oli mitmeid funktsioone, sh nii psühholoogiline kui ka maagiline roll.

\section{Урнела}

И ё вай, вай, ёx, И вай я ень, ох вай, Ай вай ёх, вай я ень.

Ужо, сявтаса шачуларинаяблунясть,

Ужо, сявтаса шачуларина тарадкесть.

Мон лопастонзо а рикстидьса, Lehtedelt ei hakka ma räsima, мон сонзэ

Мон а рикстидьса ашо шалевой Puu õied on nagu valge sall, иветензэ,

Мон а сорнувтса раужо човаля Мa ei hakka raputama õite tolmukaid. моданзо.

Ней парсей кесаксь монь кедьсэ, Nüüd kerin käes kera,

Мон келянчазьгак келянчан. Kerin ja kerin.

И я слав Боху и слав Боху, Tänan Jumalat, tänan Jumalat,

Ох, слава тебе Господи!

Пиже човоргадсь сия юткс, Сия човоргадсь пиже юткс.

Мон човоргадьнь од родняс,

Мон човоргадынь од раськес.

\section{Pulmaitk}

I jo vai, vai, joh,

I vai ja en, oh vai,

Ai vai joh, vai ja en.

Oota, raputan ounapuud,

Oota, raputan ounapuu oksakest.

(AKM: Aleksandra Kuznetsova. Tšukalõ küla, 2009. a.)

Me näeme siin võrdlusi, kus pruut on nagu valge õunapuu õis, mida ei tohi räsida. Neiu valmistub uueks eluks teises peres: "pruut sai peigmehega ühte, hõbe sai rohelisega ühte". Pruut ja peigmees - hõbe ja roheline: see värvisümboolika vihjab noorpere sündimisele. Nendes sõnades näeme rituaali siduvat osa "mina sain uue hõimuga ühte". Maagilist osa näeme episoodis, kus noor naine kerib lõngakera, tänades Jumalat, lootuses, et järgnev elu uues perekonnas toob õnne.

Järgnevalt toon võrdluseks ühe teise lauliku itku, mis oli seotud õnnistamise rituaaliga. Siin näeme tugevaid perekondlikke sidemeid ja selle tähtsust õnnistamisel ja tänamisel. Samas saab jälgida, et elu uues peres ei ole kerge. Sellele viitavad sõnad: "võõraste sugulaste meele järgi olema, vaenlaste tuju järgi elama, võõrastel on meeleolu muutlik, vaenlaste tavad on erinevad". Teksti 
vaadates tuleb esile, et õnnistust palutaksegi selleks, et elu uues peres kulgeks - õnnista mind nende meele järgi olema.

\section{Баславалонь урнела}

Баславалак, тетлй, баславалак!

Баславамак, жалил, баславалак!

Чужоень мелень ваномо,

Ятноень коронь кирдеме.

Чужоень мельтне мелекшевт,

Ятноень кортнэ корокшовт.

Пасиба, тетяй, пасиба!

Баславалак, авай, баславалак!

\section{Õnnistamise itk}

Õnnista mind, isa, õnnista!

Õnnista mind, mu hea, õnnista!

Võõraste sugulaste meele järgi olema,

Vaenlaste tuju järgi elama.

Võõrastel on meeleolu muutlik, Vaenlaste tavad on erinevad.

Tänan sind, isa, tänan!

Õnnista mind, ema, õnnista!

(AKM: Antonina Lavruškina. Ketšuševo küla, 2011. a.)

Vaenlaste ja võõraste all mõeldakse mehe sugulasi (nii ersa, mokša kui ka vene või tatari rahvusest inimesi). Siin ka selgub, et tuleb austada oma vanemaid, tuleb hästi suhtuda võõrastesse inimestesse jne.

Tänaseni on säilinud vaid mõned pulmatavad: õnnistamine, pulmapäeva määramine ja mõnes külas on taastunud neiupõlvega hüvastijätmine nelipühal. Pulmakombestik on muutunud ja pulmaitkude roll on kadunud. Itku rituaalne seos pulmadega on napp ja sel põhjusel itkusid enam ei esitata. Inimesi, kes esitasid või on kuulnud pulmades itke, on jäänud väheseks. Koos nendega kaovad käibelt ka pulmaitku tekstid.

Järgnevalt tutvustan eeltoodud näite esitanud Antonina Lavruškina itke. Aga esmalt tema eluloost, nagu ta sellest jutustas. Ta sündis 1931. aastal Mordvamaal Ardatovo rajooni Ketšuševo külas. Kogu oma elu töötas ta koduküla kolhoosis. Noorpõlvest alates on ta itke ja õigeusu kiriku laule esitanud nii peiedel kui kirikus. Itkemise traditsiooni päris ta oma perekonnast. Üheks tõsiseks tõukeks itkemisele oli ta lähedaste kaotus. Kõneldes oma elust, rääkis Antonina mitmeid lugusid metsas ja põllul töötamisest, kuid tõdes samas, et nii laulud kui ka itkud aitasid teda selle väga raske töö tegemisel, samuti rasketest hetkedest ülesaamisel. Tänapäeval kutsutakse Antoninat itkema, kui keegi sureb, ja kirikusse või peiedele õigeusklikke laule laulma (Ermakov 2014: 18). Ta valdab traditsiooni, mis seostub ersa kultuuriga.

Ersa kultuuris võib täheldada siiani alal hoitud vanu traditsioone. Samas on selle traditsiooni tundjaid ja viljelejaid vähe: need on inimesed, kes elavad peamiselt maal ja on juba küllalt eakad.

Tasahaaval on toimunud surmakujutelmadest ja matustest võõrdumine. Surm oli kui üleminek teise maailma, kus surnul jätkub samasugune olemine nagu maa peal - inimesed tegid tööd, soetasid perekonna, lõbutsesid. Kujutati 
ette, et hinge saatus teispoolsuses sõltub surnukeha juures läbiviidud rituaalidest. Seda kinnitas ka Antonina Lavruškina (AKM: 2010). Samuti oletati, et surnud esivanematel on võime hoolitseda elus olevate sugulaste eest, kuid neid aga, kes ei osutanud piisavalt austust esivanematele, võisid nad karistada (Kornišina 2000: 113-114).

Alljärgnevalt toon näite Antonina Lavruškina surmaitkust. Vaike Sarv, viidates Albert L. Lloydi itkuuurimusele toob esile surmaitku järgmised funktsioonid: "Esmalt võimaldab itkemine väljendada itkeja leinatunnet ja kergendada tema südamevalu; teiseks on see poeetiline pöördumine lahkuja poole; kolmandaks annab itkemine lahkujatele rituaalset abi uues olukorras kohanemiseks ja võimaldab mõjutada teispoolseid, et nad ei häiriks elavaid" (Sarv 2000: 97). Siinses tekstikatkes võib omakorda näha ka selle perekonna siseelu: häid suhteid ja eluraskustes üksteisest hoolimist.

\section{Ававтонь кувалт лайшела Surmaitk ämmale (katkend) (пелькс)}

Пасиба, авакай, пасиба.

Кода тон монь сречилек-

пурнылек,

Кода мон совинь тынк кудос.

Кода тон монь сречилек,

Ох, авакинел, саилил.

Кода тон жальиилить

дьь эйсел,

Остатка сускомот монень ды максылик.
Aitäh, emake, aitäh.

Kuidas sa oled mind tervitanud ja eluteele suunanud,

Kui ma tulin teie majja.

Kuidas sa oled mind vastu võtnud,

Oh, mu emake, kui kahju mul on sinust.

Kuidas oled mu eest hoolt kandnud,

Viimase leivapalukesegi mulle andnud.

Matusekombed on tänapäevalgi rituaalsed, tavakohased ja neid järgitakse täpselt. Mida arhailisem on matusekombestik, seda enam lähtub see kujutelmast, et inimese või tema hinge eksistents jätkub endisel viisil ka pärast surma. Ühtlasi sisaldab see kujutelm kartust surnu ja surma ees. Sellest kujutlusest kantuna täidab ka järgnevalt esitatud itk kaht eesmärki: kaitsta elavaid oletatava pahasoovlikkuse eest ning kindlustada surnule hea ja seisusekohane käekäik teises ilmas. Kuid sellega haakuvalt sisaldub selles surmaitkus Anna Knjazkina ja tema abikaasa miniatuurne elulugu.

\section{Лайшела лирдень кувалла Surmaitk mehele}

Ox, Мишакай, эри ялгакай, Oh, Mišake, mu elu sõbrake, Косто сась тонеть те орлась? Kust tuli sinusse see haigus?

Косто тонть муинзеть

Kuidas on sind tabanud selline tõbi?

тевате болезнясь? 
Ох, Мишакай, эйкакштнэ эзть кастовт.

Мезе карман мон сынст марто тееме?

Кода таркас, эзелс мон карман сынст лацемест?

Оx, Мишакай, ведь аволь берянь ломань ульникшныть, Превей-паро ломань, Мишакай, Tark ja hea inimene sa, Mišake, olid. ульникшныть.

Ох, ведь велесть юткова кода Oh, kui sa küla vahel kõndisid, jäid kõik ютылить, веле пештылить. Превть весе тонь кедьстэ ди кевкстильть,

Весе мелеть кепетиль тонь, Ja sinul oli selle üle hea meel, Mišake. Мишакай.

А ней мезе карлан мон тейле? Aga nüüd mida hakkan ma tegema?

Кода эйкакштнень карлан Kuidas saadan ma lapsed teele? ильтеле проужамо?

Кода карман мон сынст сречало?

И эшто, кить ведь кодаткак арасельть,

Транспорт кодалояк дьь ведь арасель.

Кода минь срадали дь эйкакштнэнь марто.
Oh, Mišake, meie lapsed pole veel täiskasvanud.

Kuidas saan nendega hakkama?

Kuidas panen nad kirstu kõrvale seisma?

Oh, Mišake, pole paha inimene sa olnud, vaatama.

Nõu ja tarkust sinult kõik küsisid,

Kuidas tulen ma nendele vastu?

Ja see ka, kui halvad on teed olnud, Mingisugust transporti ka ei olnud.

Kui palju kannatasime lastega.

(AKM: Anna Knjazkina. Lunga küla, 2011. a.)

Selles itkus kajastub poeetilises vormis lahkunu iseloom ja saatus. Itk lähtub surnud mehe eluloost ja tema perekonnast. Siin kasutatakse traditsioonilist skeemi ja sõnastust, mis siiski võimaldab itkus väljendada konkreetset leina konkreetse inimese surma puhul. Itku tekstist on näha, et kõnetatakse lahkunu hinge. Kesksel kohal on kurbust väljendavad hüüded ja küsimused (Miks surid? Miks läksid? Kuidas saadan lapsed teele? Kuidas tulen nendele vastu?). Tunnuslikud on ka raske elu, leina ja kahjutunde üle kurtmised. Samas näidatakse ka teatud perioodi olustikku. Näiteks mainitakse sõidutee puudumist (halvad on teed), mis viitab 1980.-1990. aastatele. Itkudes on palju improvisatsioone: tekstid mõtestatakse vastavalt hetkeolukorrale ümber ja lisatakse uusi osi. Muutused puudutavad ka keelt. Eeltoodud näitetekstis kasutab esitaja tänapäeva ersa keelt, kus on laensõnu vene keelest. 
Varasemad teadusuuringud ja allikmaterjalid näitavad, et maakohtades säilivad traditsioonilised itkud ja nendega seotud kombed paremini kui muu rahvakombestik (näiteks uusaasta vastuvõtt, sünnipäevad ja muudki meelelahutusega seotud kombed ning tavad). Üldlevinud on seisukoht, et matusetraditsioonid on siirderiituste hulgas kõige konservatiivsemad. Ka käesolev uurimus ersa itkudest kinnitas seda. Kui võrrelda ersa matusekombestikku eesti ja setu omaga, selgub, et ersa matusekombestikus on elujõulisena püsinud arhailisi jooni märkimisväärselt enam. Postmodernistlikus Setumaa ühiskonnas mõjutab rahvakultuuri, sealhulgas ka matusekombeid, suuresti kommertskultuur, mordva-ersadel on see mõjutus palju väiksem. Näiteks Marju Kõivupuu märgib, et traditsioonilise matusekombestiku asemel annab tooni matusebüroo teenuste kasutamine, mis pakuvad leinajaile kõikvõimalikke matusetalitusega seotud teenuseid alates surnu transportimisest külmkambrisse, surmakuulutuse ajalehte panekust ja lahkunu kremeerimisest kuni hauaplatside kujundamiseni. Samas tuleb arvestada, märgib Kõivupuu, et matusekombed püsivad visalt edasi ka siis, kui kultuurimuster on muutunud. Matusekommete kandumisel ühest põlvkonnast teise pole esmane eelmiste põlvede kommete ja tavade mehaaniline kopeerimine traditsiooni enda pärast, vaid iga järgmine põlvkond võtab eelmistelt põlvedelt üle selle, mis on talle väärtuslik ja tähtis ning mis sobitub uuenenud kultuuripilti (Torp-Kõivupuu 2003: 149-151). Rahvakultuuris üldiselt toimunud muutused on kaasa toonud kombestiku transformeerumise ja kadumise, kuna kombestik ei rahulda enam inimeste vajadusi. Sellegipoolest, nagu märgib Galina Kornišina (2008: 6), säilitab kombestik vaatamata olulisele lõhutusele ja paratamatutele evolutsioonilistele ümberkujunemistele võrdlemisi arhailise struktuuri elemente.

Analüüsides tänapäevast itkukombestikku, ilmneb, et mitmedki kombed on arhailise taustaga. Ka praegu järgitakse ersa külades toimuvatel matustel eelpool kirjeldatud kombeid. Lisaks tuleb ka seda tõdeda, et mida vaesem on kogukond ja traditsioonilisem nende elulaad, seda paremini säilivad traditsioonilised kombed (vrd Torp-Kõivupuu 2003). Paremini on traditsioonid säilinud perifeersetes külades. Ka tänapäeval mälestatakse kõiki sugulasi ühiselt. Seda tehakse ülestõusmis- ja suvistepühal, kaasani maarjapäeval ${ }^{3}$ ja teistel kirikupühadel. Nendel päevadel minnakse kalmistule, võttes kaasa toidukraami. Alguses toimub ühine hingepalvus, seejärel minnakse laiali sugulaste haudadele, kus mälestatakse koos perega lahkunuid. Kalmule pudistatakse toitu, kallatakse jooke, jäetakse raha. Vastlapäeval ja Dimitri laupäeval ${ }^{4}$ mälestatakse kõiki surnuid kodus. Lauale pannakse sool ja leib, kruus meekaljaga ja muud toidupoolist.

Itkutekstides, lauludes, kommetes ja küsitletud inimeste muudes ütlustes kajastub arusaam, mille järgi surnud võivad elavaid abistada. Surnutelt 
palutakse tervist, lasteta naised paluvad abi laste saamiseks. Eriti püsivalt on säilinud põua ajal vihma palumise tava. Luvnes näiteks palvetavad eakad naised siiani, et paluda vihma või vastupidi, kui vihma sajab kaua, siis paluvad nad, et vihmaperiood lõpeks. Palvetamisekoht on kalmistu või mägi, sest inimesed arvavad, et mäel asudes on nad lähemal surnutele ja Jumalale. (AKM.)

Üldistavalt võib öelda, et Mordva Vabariigi Ardatovo rajoonist minu välitöödel kogutud itkurepertuaari ja itkude esitajate kaudu avaneb mordva-ersa rahvaluule ühe žanri - itku - struktuur. Ühtlasi saab jälgida itkude arengutendentse ja esitajate eluraskuste kajastumist neis traditsioonilisse kombestikku kuuluvates tekstides.

Vahelepõikena tutvustan itke ja itkejaid tänapäeva kultuuris, mida võib vaadata kui itkutraditsiooni uut eluetappi. Tänapäeval esitatavad traditsioonilises vormis itke laval sellised folklooriansamblid nagu Merema, Torama, Oyme, Mordens. Kõige nooremaks itkude esitajaks on Katerina Modina, kes sündis Sosnovobordski rajoonis Penza oblastis Vatšalei külas 1986. aastal. Ta on folklooriansambli Merema juht. Ta esitab laval nii pulma- kui ka surnuitke. Ainese oma esitusteks saab ta folkloori kogumise ekspeditsioonidelt. Alguses ta ainult kuulas itke ja itkejate lugusid. Hiljem hakkas ta neid salvestama ja alles seejärel ise neid esitama. Esimest korda kuulsin tema itkulaulu esitust Eestis Moostes 2013. aastal toimunud festivalil "Moisekatsi elohelü".

Lähemalt tutvustaksin üht itkude meesesitajat Gennadi Dulkinit. Ta sündis 1965. aastal Mordvamaal Kotškurovo rajoonis Sabaevo külas. Ta esitab itke juba paarkümmend aastat, tehes seda meisterlikult nii traditsioonilises keskkonnas kui ka laval. Tema enda sõnul pärinevad tema oskused perest, kust ta pärit on. Vahendan taas jutustaja vaadet oma perepärimusest. Gennadi ema Anastasssia Dulkina (1931-2011) oli professionaalne itkeja mitte ainult oma kodukülas, vaid terves rajoonis. Teda kutsuti tihti itkema, kuna ta oli võimekas sõnaseadja ja improviseerija. Anastassia ema Akulina Tšetaikina oli samuti tundud itkeja, kes oli pärit Mordvamaa Bolšebereznikovski rajoonist Permisi külast. Gennadi vanaisa oli ta naiseks varastanud (õigemini tõmmanud), kuna Akulina vanemad polnud nõus tütart talle naiseks andma. Kuid noored olid teinud oma valiku. Gennadi vanaisa andis naisele ersa nime Nuja. Kõike seda teadis Gennadi vanaema ja ema itkudest ja perelugudest. Noormees kuulas itke lapsest saadik ja ta sai aru itkemise peentest nüanssidest. Kui ta ema suri, oli itk noormehele abiks: just itkedes oli noormehel kergem kaotusvalu taluda ja leinaga toime tulla. Ühtlasi said lähedalolijad kuulda Gennadi pere lugu. Ta väidab, et iga itku esitamisega tekib tal väga tugev side ema ja esivanematega. Just itkud on tema meelest kõige südamlikumad ja ilusamad laulud.

Lisaks perest päritule mõjutasid teda rahvaluule kogumise ekspeditsioonid ersa ja mokša piirkondadesse. 1989. aastal lõid nad koos tuntud folkloristi 
Vladimir Romaškiniga legendaarse meesteansambli Toorama. Alates 2012. aastast laulab ta Merema ansamblis, mis esitab ka itke. Tema salvestatud itke saab kuulata Lelo plaadilt (Matka suomalais-ugrilaisen musiikin maailmaan), mis ilmus Soomes 2007. aastal (itkud nr 4, 6 ja 10). Võib kuulata ka muid itke, heliplaadilt Sylgam (heliplaat Traditional Songs of Mordovia, Global Music Centre 2005, itkud nr 4 ja 9).

Viimasena tutvustan Ardatovo rajooni Luvne külast pärit ravitsejat Jelena Konstantinovat (1931-2012), keda näen eelnevate informantide vastandina: tema ei esitanud mulle itke spetsiaalselt uurimuse jaoks, vaid andis ülevaate itkudega seotud kommetest ja tavadest (näiteks esitas õnnistamissõnu). See materjal aitas paremini itkemist mõista ja tõlgendada. Jelena jutustas oma eluloost järgmist. Ta oli lapsepõlves jäänud orvuks (nagu Aleksandragi). Et mitte nälga surra, käis ta teistes külades, elatudes vaimulike laulude laulmisest ja inimeste ravitsemisest. Tema sõnutsi oli ta kogu oma elu söönud vaid seda, mida oli ise kasvatanud. Jelena loobus rahast, pensionist, elektrist - ta elas askeetlikult. Elamiseks vajas ta vaid Jumala armu ja oma tööga teenitud toitu - nimelt võttis ta palga asemel vastu leiba ja muud toidupoolist. Jelena ei oleks rääkinud mulle oma nooruspõlvest ega ravitsemisest, kui minuga koos ei oleks olnud tema sugulane, kes mind küsitlemisel aitas.

Artikli lõpuks tutvustan nekrutiitke ja nendega seotud lugusid. Nekrutiitkud on seotud noormeeste sõjaväeteenistusse saatmisega. Need tekkisid ammu enne seda, kui Peeter I kehtestas 17. sajandil nekrutiks võtmise, ja kus noormehi värvati sõtta otsekui surma saates (Mordovija 2003: 201). Need varasemad sõjad, kus mordva vürstid sõdisid vene vürstide vastu, toimusid aastatel 1103, 1120, 1186, 1205, 1220. Vanades nekrutiitkudes kujutatakse tsaarivõimu, selle ajastu aluseid ja teenistuse raskust.

Mitme sajandi jooksul on nekrutiitkud funktsioon transformeerunud. Itkudest on saanud kurvad lüürilised laulud. Nekrutiitkude üleskirjutuste vähesus on tingitud sellest, et see žanr taandus käibelt peaaegu täielikult 20. sajandi keskpaigaks. Ometi toimus sajandi teisel poolel selle žanri taassünd, seda seoses ühiskondlik-poliitiliste sündmustega Venemaal, mis puudutasid ühel või teisel viisil ka ersalasi. Need olid sõjad Afganistanis (1979-1989) ja Tšetšeenias (1992-1997), mis tõid kaasa noorte meeste armeesse värbamise kõrval ka võimaluse, et nad hukkuvad lahingutes. Nii saatsidki ersa naised oma poegi armeesse (võimalikku sõtta) itkedes. Seda võib mõista kui kriisiolukorda, kus rahvas pöördub tagasi oma vanade tavade ja rituaalide poole, et sellest tuge leida.

Ka tänapäeval pöörduvad noormehe sugulased teda sõjaväkke saates koduhaldjate ja Jumala poole. Selle pöördumisega algabki tavaliselt nekrutiehk soldatiitk. Ühtlasi demonstreerib itkejanaine ka mütoloogilise maailma 
ja õigeusu reeglite tundmist. Sellele järgneb sõjaväkke saadetava noormehe kirjeldus. Tavaliselt on nekrutiõnnistamise tekst järgmine:

Баславало арлияв тулосто

Микола Милостливой,

Спаситель Божиматерь!

Сохрани, Господи, минек чадамок!

Кода ильтсынек шумбрасто,

Истя сречасынек шумбрасто.

Спаси! Сохрани! Спаси! Сохрани!
Õnnistamine sõjaväkke minekul

Mikola Armulik!

Päästja Maarja!

Hoia, Jeesus, meie last!

Nagu saadame ta tervelt,

Nõnda vastu võtame tervena.

Päästa! Hoia! Päästa!

(AKM: Antonina Lavruškina, 2011. a.; Jelena Konstantinova, 2011. a.)

Õnnistamissõnade järel suudleb noormees kolm korda ikooni, mille kohal itkeja teeb kolm ristimärki ja seejärel õnnistatakse noormeest ikooniga veel kolm korda (AKM: Jelena Tarnaeva; Jelena Konstantinova; Antonina Lavruškina, 2011). Vanemad õnnistavad oma poega tavaliselt selliste sõnadega: "Õnnistagu sind koduhaldjas Keren šocko!” (Jevsevjev 1961-1966: 5, 306; Kornišina 2000: 57). Õnnistamise ajal on tavaks nutta. Mordvalaste ristiusustamise tõttu on järkjärgult kadumas usk jumalatesse ja müütilistesse jõududesse, kuid ülalmainitud itkudes on selle järelkaja säilinud kas loitsimiste kujul või pöördumistes jumalate poole, mida võisime näha ka eeltoodud itkus.

Itkudega seotud uskumused ja kombed moodustavad rahvakultuuris omaette teema. Iga ajajärk on siia ladestanud oma arusaamu ja tavasid, mis on kas varasematega põimunud või eelmised välja tõrjunud. Selle tulemusena on välja kujunenud keerukas rituaalide kogum, mille põhjal täidetakse paljusid tavasid vaid seetõttu, et nii on varem tehtud ja nii näeb ette traditsioon.

\section{Kokkuvõte}

19. sajandi lõpust kuni käesoleva ajani on paljud itkud ja nendega seotud kombed märkimisväärselt muutunud, taandunud ja kohati hääbunud, kuid itkemise ja itkejatega seotud lood on tänapäeva uurijale kõnekad. Kuna itkude põhilised esitajad aja möödudes elust lahkuvad, võib see ersa kultuuri unikaalne osa lõplikult kaduda. Seepärast on jätkuvalt vaja teha igakülgseid teadusuuringuid, mis muude uurimisaspektide kõrval lähtuks vaimsete väärtuste põlvest põlve edasiandmise mehhanismide jälgimisest, sh teha nii tagasivaateid, talletada uut laadi allikmaterjali (nagu antud juhul elulooline aines) ja jälgida itkutraditsioonist võrsuvaid tänapäevaseid edasiarendusi ja esitusi. Itkudes peituvates ja itkejate jutustatud lugudes leidub mitmeid minibiograafiaid 
ja muid teateid, mis jäädvustavad nüüd ka kirjas inimeste omaaegse elu. Nende põhjal on võimalik saada ettekujutus rahva olmest, traditsioonidest ja maailmavaatest. Kõne all olnud itkejad olid kõik erineva sotsiaalse taustaga, kuid kõik nad olid ja on külaühiskonnas austatud.

Möödunud sajandi keskpaiku toimusid itkude ja itkejatega seoses olulised muutused. Pulmaitkud hakkasid vähehaaval kaduma, praegu mäletavad neid veel vanemad naised (AKM). Kombe taandumine on seotud pulmakommete endi muutustega, aga samuti neid itke esitava pruudi staatuse muutumisega. Mis puudutab matuselaule, siis need on oma tähendust ja koloriiti kaotanud vähem. Matuse- ja leinakombestik on külakohtades säilinud palju täielikumalt kui teised rituaalid, kuna nende kandjaks on külades eakad inimesed, kes hoiavad rahvakombeid juba oma eluea tõttu kauem alal. Näiteks paluvad vanad inimesed enamasti matta end esivanemate kombel - "vastavalt seadusele" (AKM). Tähelepanu väärib ka tõik, mida toob esile Eesti uurija Marje Joalaid: traditsioonilist itku esitavad eakad inimesed mitte ainult seepärast, et nad tunnevad tavasid paremini kui noored, vaid ka seepärast, et noored ei ole itkude esitamiseks küpsed (Joalaid 2000: 276). Traditsiooni tundmise ja väärtustamise kõrval nõuab itkemine eriti matustel ja sõjaväkke (sõtta) saatmisel elukogemust. Välitöödel kogutud elulooline aines viitas seostele itkejaks saamise ja elukogemuse vahel. Esile tuli vaeslapseks olemise ja raske töö kogemise osa itkemise kui selle kultuuriilmingu olemuse tunnetamisel ja sealt edasi ka itkuteemade kujundamisel. Nooremate vastajate puhul, kes itkutraditsiooni valdasid, ilmnes nt itkemise traditsiooni tugevus pere raames: selles omandati nii oskus kui ka vajadus seda teatud elusituatsioonides kasutada.

Nii välitöömaterjalist kui ka itkudest ilmneb, et peamiselt on naine see, kes tagas ja tagab ka praegu muistsete tõekspidamiste, kommete ja traditsioonide säilimise mordva ühiskonnas. Setu itkukultuuri uurinud Vaike Sarv toob samuti esile, et itkemine oli naiste traditsioon - "selle sotsiaal-kultuuriline struktuur, usundiline taust ja ka keel erines märgatavalt meeste kultuurist. Itku ehmatav ekspressiivsus mõjus selliselt, et neid meestekesksesse rahvuskultuuri kaasa ei haaratud" (Sarv 2000: 97). Ometi on erandlikke näiteid (mis artiklis ka kõneks olid), kus itkutraditsiooni kannab edasi mees.

Mordvamaal on päevikuid, kirju või muid dokumente itkejate või pärimuse tundjate kohta vähe säilinud. Allikate nappuse tõttu on ka autobiograafilised lood ja biograafiline uurimisviis senini jäänud tähelepanuta. Biograafilise uurimisviisi kaudu aga näeme ühiskonnaelu peegeldust: arenguid, muutusi, leppimist oma saatusega, kompromisside tegemist jne. Välitööd osutusid sellealase materjali talletamiseks asendamatuks. Ühtlasi väärib tähelepanu see, kuidas uurija biograafia mängib olulist rolli sellise tundliku ainese kogumisel. Olles uurija, olen ühtlasi nende inimestega seotud ka sama kogukonna, maa- 
elu ja ilmavaate kaudu. Välitööl kogutu ja selle artikli ainesega seotud mõtete kirjapanekud kavatsen anda Eesti Rahvaluule Arhiivi.

\section{Kommentaarid}

1 Artikkel on ilmunud Eesti Keele Instituudi eesti-ersa sõnaraamatu projekti raames ja Suomalais-Ugrilainen Seura toetusel.

2 Petrus Petrejusest (umb 1570-1622) ja tema uurimusest "Historien und Bericht von dem Grossfürsthentumb Muschow..." (Ajaloolised jutustused ja teated Moskva suurvürstiriigist...) ja selle saksakeelsest publikatsioonist (1620) on pikemalt kirjutanud Kari Tarkiainen (2017). Toimetaja märkus.

${ }^{3}$ Kaasani maarjapäev (22. oktoober / 4. november) on Vene-õigeusukiriku püha, millel on seos Venemaa ajalooga (Hiiemäe a-ta).

4 Dimitri laupäev on Vene-õigeusu kirikukalendri tähtpäev, 26. oktoobrile / 8. novembrile eelnev laupäev, mis pühendatakse surnud esivanemate mälestamisele (Hiiemäe a-ta).

\section{Allikad}

AKM - autori kogutud materjal, talletatud välitöödel Mordvas ajavahemikus 2000-2013. Materjal on autori valdustes.

Respublika Mordovija (http://www.emordovia.ru/content/view/874 - 25. mai 2018).

\section{Kirjandus}

Arukask, Madis 2011. Suheldes üle piiri: ekshumatsioon ja surnuitkude žanriline mälu. Mäetagused 47, lk 39-63 (doi: 10.7592/MT2011.47.arukask).

Devjatkina, Tatjana 1992 = Deviatkina, Tat'iana Petrovna 1992. Mokshanskie svadebnye obriady i pesni: V proshlom i nastoiashchem. Saransk: Mordovskoe knizhnoe izdatel'stvo.

Ermakov, Natalia 2011. Tänapäeva ersa-mordva itkud. Neen' shkan' erzian' laishemat dy urnemat. DVD. Tallinn.

Ermakov, Natalia 2014. Erzianskie prichitaniia: traditsii bytovaniia i sovremennoe sostoianie. Tallinn: Tallinna Ülikool, Eesti Humanitaarinstituut.

Hiiemäe, Mall (a-ta). Mordva rahvakalender (E-publikatsioon http://www.folklore.ee/ rl/folkte/sugri/mordva/rk/ - 24. mai 2018).

Honko, Lauri 1963. Itkuvirsirunous. Kuusi, Matti (toim). Suomen kirjallisuus I. Kirjoittamaton kirjallisuus. Helsingi: Suomalaisen kirjallisuuden seura \& Otava, lk 81-128. 
Honko, Lauri 1998. Folklooriprotsess. Mäetagused 6, lk 56-84 (doi: 10.7592/MT1998.06. honko).

Jackson, Bruce 1987. Fieldwork. Chicago: University of Illinois Press.

Jevsevjev, Makar 1961-1966 = Evsev'ev, M. E. Izbrannye trudy. V 5 tomakh. Saransk: Mordovskoe knizhnoe izdatel'stvo, t 2 (1963); t 5 (1966).

Jevsevjev, Makar 2004 = Evsev'ev, M. E. Zhizn' mordvy v fotografiiakh. K 140-letiiu so dnia rozhdeniia. Fotoal'bom. Saransk: Mordovskoe knizhnoe izdatel'stvo.

Joalaid, Marje 2000. Itk vepsa matusekombestikus. Salve, Kristi \& Kõiva, Mare \& Tedre, Ülo (koost). Tagasipöördumatus. Sõnad ja hääl. Tartu: Eesti Kirjandusmuuseumi folkloristika osakond, lk 265-282.

Korb, Anu 2007. Siberi eesti kogukonnad folkloristliku uurimisallikana. Dissertationes folkloristicae Universitatis Tartuensis 8. Tartu: Tartu Ülikooli Kirjastus (http://dspace. ut.ee/handle/10062/3421 - 25. mai 2018).

Kornišina, Galina 2000 = Kornishina, G. A. Traditsionnye obychai i obriady mordvy . Istoricheskie korni, struktura, formy bytovaniia. Saransk: MGPI.

Kornišina, Galina 2005 = Kornishina, G. A. Traditsionno-obriadovaia kul'tura mordvy. Uchebnoe posobie. Saransk: Tipografiia Poligraf.

Kornišina, Galina 2008 = Kornishina, G. A. Ekologicheskoe vozzrenie mordvy. Religioznoobriadovyi aspekt. Saransk: Izdatel'stvo Mordovskogo universiteta.

Mordovija 2003 = Mordoviia-Mordoviia 2003-2004. Entsiklopediia: V 2-kh t. Saransk: Mordovskoe knizhnoe izdatel'stvo.

Pino, Veera 2000. Setu matusekombestik. Salve, Kristi \& Kõiva, Mare \& Tedre, Ülo (koost). Tagasipöördumatus. Sõnad ja hääl. Tartu: Eesti Kirjandusmuuseumi folkloristika osakond, lk 38-54.

Rüütel, Ingrid 2009 = Riuitel', I. Kikhnuskie svadebnye obriady v finno-ugorskom kontekste. Finno-ugorskii Mir 1, lk 62-75.

Sarv, Vaike 2000. Setu itkukultuur. Ars Musicae Popularis 14.Tampere \& Tartu: Eesti Kirjandusmuuseumi etnomusikoloogia osakond \& Tampereen yliopiston kansanperinteen laitos.

Tarkiainen, Kari 2017. Petrus Petrejus ja Liivimaa ajalugu. Kaju, Katre (koost). Kroonikast epitaafini. Eesti- ja Liivimaa varauusaegsest haridus- ja kultuurielust. Rahvusarhiivi toimetised. Acta et Commentationes Archivi Nationales Estoniae 1 (32), lk 13-35.

Torp-Kõivupuu, Marju 2003. Surmakultuuri muutumine ajas: ajaloolise Võrumaa matusekombestiku näitel. Tallinn: Tallinna Pedagoogikaülikooli Kirjastus.

\section{Videonäited}

www.youtube.com: Natalia Ermakov. DVD: Tänapäeva ersa-mordva itkud. Videomontaaži on teinud Maido Selgmäe (https://www.youtube.com/watch?v=qoQbONR-doQ). 


\title{
Mordvamaa kaart
}

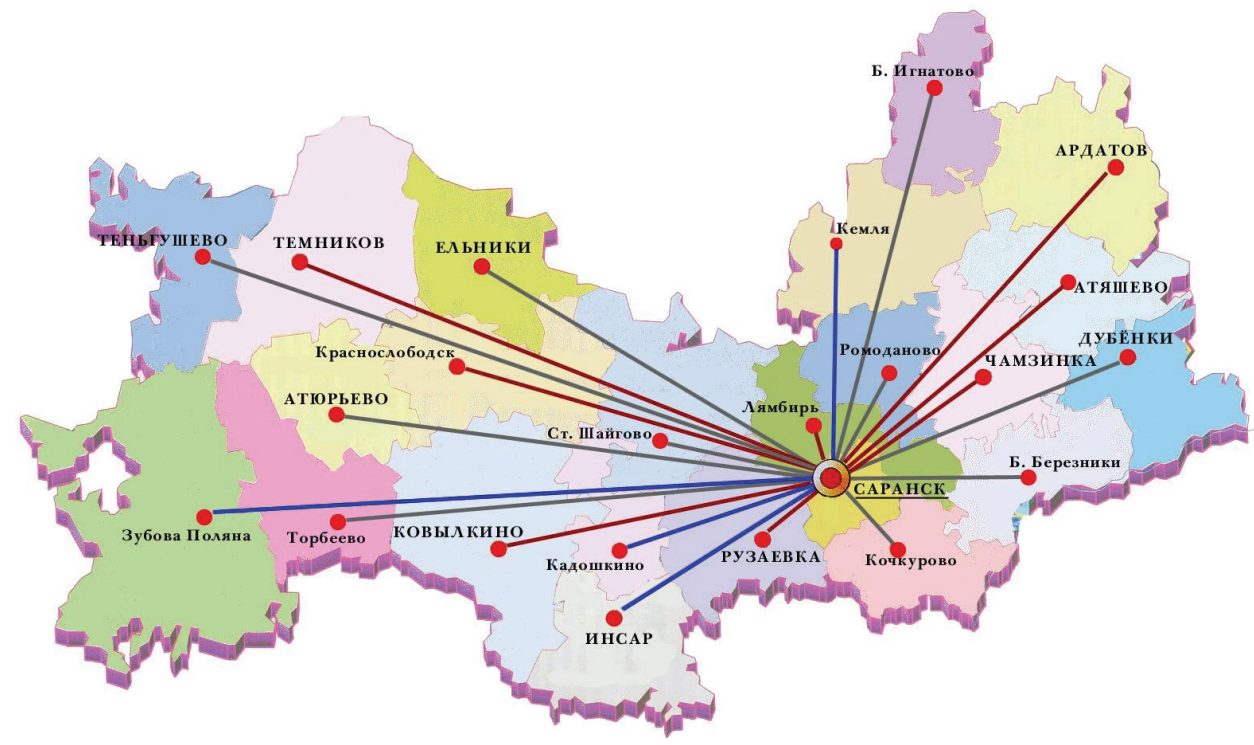

URL: http:/ /www.e-mordovia.ru

\section{Summary}

\section{Songs of lamentation and lamenters from the biographical perspective: Analysis of the material recorded during field studies}

\author{
Natalia Ermakov \\ Lexicographer, Institute of the Estonian Language \\ ermakov.natalia@gmail.com
}

Keywords: biography, Erzya lamenting tradition, field studies, songs of lamentation

The article addresses the texts of laments, biographies of lamenters, and the context of customs related to lamenting. The analysed biographies and songs of lamentation were gathered between 2000 and 2013 (Ermakov 2011; 2014: 16-24) and represent the traditions of Ardatovo district of the Republic of Mordovia. The Mordvins are a Finno-Ugric people living in Russia, who have a republic of their own within the Russian Federation $\left(26,200 \mathrm{~km}^{2}\right)$, with Saransk as its capital. The respondents were born in the late $1920 \mathrm{~s}$ and early 1930s. For the sake of comparison, representatives of a younger generation born between 1964 and 1980 were also interviewed. All of them live in the countryside. 
The biographies of lamenters and texts of songs of lamentation provide an overview of the cultural and historical environment of the period. Among other things, the article presents observations on religious taboos concerned with the recording of these songs. Lamenters in their immediate environment are also described.

The article aims to discuss lamenting, songs of lamentation, and the living environment of lamenters, focusing on the biographical aspects contained in these songs. As a song of lamentation is a traditional form of expressing sorrow and mourning, it is a genre with poetically quite well-developed representation language. At the same time, a song of lamentation is linked to the person's stages of life and is always personalized, which justifies viewing the tradition of lamenting from the biographical perspective. The first part of the article introduces the material for analysis, recorded during field studies, and provides an overview of Mordvin, particularly Erzya lamenting tradition. The second part of the article describes lamenters through their biographies told by themselves, and stories recorded during field studies, and analyses the artistic language of the songs of lamentation, highlighting the connection of the poetics developed over centuries (i.e. the collective common language) with historical and personal specifics. The article concludes with an overview of a present-day performance of songs of lamentation, which, in its turn, can be interpreted as the life story of the lamenting tradition.

Only few diaries, letters, and other documents about lamenters or those who know traditions have been preserved in Mordovia. Due to the scarcity of sources, biographical research as well as autobiographical stories have been somewhat overlooked so far. However, it is through biographical research that we can see the reflection of society's life: developments, changes, accepting one's fate, making compromises, etc. Field studies proved to be irreplaceable for the preservation of such material. 